\title{
Promoting organic pigmented rice: A study to develop sustainable agroindustry in Indonesia
}

\author{
Fadhila Wijayanti ${ }^{1, *}$, Dyah Ismoyowati $^{1}$, and Makhmudun Ainuri ${ }^{1}$ \\ ${ }^{1}$ Department of Agroindustrial Technology, Universitas Gadjah Mada, Yogyakarta, Indonesia
}

\begin{abstract}
Increased environmental awareness has made consumers switch to consuming organic food. One of the most popular preferences of organic foods is organic pigmented rice. Market information regarding consumers who are aware of the environment in pigmented rice oriented towards organic and sustainable products is still needed. For this reason, this study aims to determine consumer attitudes towards green products and how much influence consumer attitudes towards purchase intention of organic pigmented rice. The type of research used in this study is descriptive quantitative with survey methods. Research data were derived from Indonesian consumers and obtained valid responses from 309 participants. The analysis technique used is simple linear regression. The results showed that the variable attitude towards green products had a positive and significant effect on green purchase intentions. The attitude variable towards green products can explain the variance of green purchase intention of $44.3 \%$, while $55.7 \%$ are influenced by other variables not examined in this study. The study concludes that the promotion program by relevant stakeholders must focus on the environmental and health benefits of organic pigmented rice that is produced sustainably.
\end{abstract}

\section{Introduction}

Current global trends lead to a healthy lifestyle and correlate with the consumption of environmentally friendly products. Eco-friendly products are increasingly popular with consumers because they care about their health and protection of the environment [1]. According to [2] stated that consumers' concern for the environment affects their behavior towards purchasing organic products. One of the most popular preferences of organic foods is organic pigmented rice. Organic rice is rice derived from rice that is cultivated organically or without using chemical fertilizers and pesticides and applies an organic food system up to the hands of consumers so that it is considered environmentally friendly [3]. Organic pigmented rice is considered a healthy food because it contains fiber, antioxidants, vitamin E, protein, iron, and other nutrients. Besides, the low sugar content in pigmented rice can reduce blood sugar levels.

The measurement of consumer attitude is a central issue in many marketing situations [4]. Market segmentation strategies are often data about attitudes. Determining the attitudes of different market segments to a product is essential for developing an attitude

\footnotetext{
* Corresponding author: fadhila.wijayanti@gmail.com
} 
measurement strategy is often the basis for evaluating how consumers respond to a product. Research that has been done also supports the theory that there is a positive relationship between attitudes and purchase intentions $[5,6]$.

Market information regarding consumers who are aware of the environment in pigmented rice oriented towards organic and sustainable products is still needed. For this reason, this study aims to determine consumer attitudes towards green products and how much influence consumer attitudes towards purchase intention of organic pigmented rice. So, it can be known how to increase sales and to overcome marketing problems for farmers in Indonesia.

\section{Literature review}

\subsection{Pigmented Rice}

Pigmented rice in this study was red rice and black rice. Due to its aleurone, red rice contains genes that produce anthocyanins, which are a red or purple source. Black rice, caused by aleurones and endosperm, produces anthocyanins with high intensity so that it has a dark purple color close to black [7]. Black rice is a healthy food source that contains fiber, minerals, and phytochemicals [8]. The increasing awareness of consumers about healthy lifestyles and changes in the diet has made organic colored rice increase.

Red rice contains anthocyanins, which are antioxidants and a source of red or purple color. Anthocyanin compounds can reduce inflammation, allergies, lower cancer risk, and help with weight loss. Red rice is often recommended for consumption by people with diabetes and heart disease. The content in red is thought to reduce arterial plaque, prevent cardiovascular risk, lower high cholesterol, and reduce diabetes risk. Black rice has better nutritional content than red rice and red rice. Black rice contains fiber, antioxidants, phytonutrients, vitamin E, protein, iron, and other nutrients. Experts consider black rice to have benefits for the liver, kidneys, and stomach. Black rice is recommended for people with heart disease, diabetes, and high blood pressure [10].

\subsection{Consumer Attitude}

Attitude is an expression of inner feelings, which reflects whether someone likes or dislikes and agrees or disagrees with an object. The measurement of attitude is a central issue in many marketing situations [4]. Market segmentation strategies are often data about attitudes. Determining the attitudes of different market segments to a product is essential for developing an attitude measurement strategy is often the basis for evaluating how consumers respond to a product.

In the research conducted by [11], what is meant by attitudes towards the environment is an individual assessment and a cognitive measurement of the value of caring and protecting the environment. Attitudes towards the environment can also be defined as a way of thinking, feeling and acting on several aspects of the environment. There are three components of attitude, namely cognitive, affective and behavior. Cognitive means an individual's belief or knowledge of an object. Affective means feelings or emotional reactions to objects. Whereas behavior, reflects the visible actions and statements of behavioral intentions by considering the physical attributes of an object [4]. 


\subsection{Purchase Intention}

Purchase intention can be defined as a positive tendency in individual actions to buy a brand that matches the purchase motive with the characteristics of a brand [12]. In this study, the intention to purchase green products is defined as the desire or plan of consumers to buy environmentally friendly products or green products. According to [13], the intention to buy green product or environmentally friendly products is the possibility and willingness of someone to buy products that have environmentally friendly features. Eco friendly refers to goods and services, regulations, guidelines, policies that lead to activities that reduce impacts, or activities that are completely harmless to the ecosystem [14]. The factors that influence the intention to purchase environmentally friendly products can be grouped into five factors, namely: demographic factors, ecological knowledge factors, value factors, attitude factors, and behavioral factors [15].

\section{Research Methodology}

\subsection{Data Collection}

The research was conducted in January - May 2020. A preliminary questionnaire was given to 40 respondents and tested for validity and reliability in order to see whether the questionnaire was valid and reliable. Then the questionnaires were distributed again and the research respondents were 309 respondents. The distribution of questionnaires was carried out by online surveys of respondents who knew and had the intention of buying pigmented rice in Yogyakarta, Semarang, Jakarta and Bali. These cities are big cities in Indonesia. The marketing of pigmented rice from Yogyakarta is mostly marketed to other cities such as Jakarta, Bali, Semarang, and others [16]. Each research variable was measured using a Likert scale to measure attitudes towards purchasing green products $[17,18]$. The indicator of purchase intention for green products is based on previous research theory and was adopted from $[19,20]$. The questionnaire consists of basic information in the form of sociodemographic respondents, consumer attitudes, and green purchase intentions. In this study the independent variable is consumer attitudes while the dependent variable in this study is green purchase intention.

\subsection{Data Analysis}

Furthermore, the research data were analyzed through validity test, reliability test, classical assumption test, and simple linear regression. The simple linear regression equation in general is as follows:

$$
Y=a+b X
$$

$\mathrm{Y}=$ dependent variable, $\mathrm{a}=$ constant $(\mathrm{Y}$ value if $\mathrm{X}=0), \mathrm{b}=$ regression line direction coefficient, and $\mathrm{X}=$ independent variable

\section{Result and Discussion}

\subsection{Respondent Characteristic}

The total respondents in this study were 309 respondents, there were 198 respondents (64\%) female and 111 (36\%) male. Respondents with female gender are more dominant than the male gender. These results can illustrate that most of the activities or shopping 
activities are women. Consumers at that age have a responsibility to fulfill their needs. It was shown that the age group consuming pigmented rice the most were those aged 25-34 years with $73 \%$ or 226 respondents. Most of the respondents in this study were unmarried, namely 171 people or $55 \%$. Most respondents were those with the latest undergraduate education, as many as 229 people or $77 \%$, followed by respondents with the latest postgraduate education as many as 40 people or as many as $13 \%$. This shows that with a high level of education, consumers are aware of the importance of health, in this case buying pigmented rice. The majority of respondents work as private employees, namely 129 people $(42 \%)$. Most of the respondents had an income per month above IDR $10,000,000$ as many as 83 people $(27 \%)$. This is related to the majority of respondents aged 25-34 years, as many as 73\% are of productive age and have a higher education level, namely undergraduate and postgraduate.

Table 1. Characteristics of research respondents

\begin{tabular}{|c|c|c|c|}
\hline Varaibel & Categories & Frequency & Percentage \\
\hline \multirow{2}{*}{ Gender } & Male & 111 & 36 \\
\hline & Female & 198 & 64 \\
\hline \multirow{4}{*}{ Age } & $15-24$ years & 43 & 14 \\
\hline & $25-34$ years & 226 & 73 \\
\hline & $35-34$ years & 34 & 11 \\
\hline & $45-54$ years & 6 & 2 \\
\hline \multirow{4}{*}{ Education } & High school & 28 & 9 \\
\hline & Diploma & 3 & 1 \\
\hline & Graduate & 229 & 77 \\
\hline & Post-graduate & 40 & 13 \\
\hline \multirow{3}{*}{ Marital status } & Single & 170 & 55 \\
\hline & Married & 71 & 23 \\
\hline & Married with kids & 68 & 22 \\
\hline \multirow{7}{*}{$\begin{array}{l}\text { Employement } \\
\text { status }\end{array}$} & College student & 48 & 16 \\
\hline & Government employees & 28 & 9 \\
\hline & Private employees & 129 & 42 \\
\hline & Housewife & 19 & 6 \\
\hline & $\begin{array}{l}\text { Employee of state-owned } \\
\text { enterprises }\end{array}$ & 34 & 11 \\
\hline & Entrepreneur & 38 & 12 \\
\hline & Other & 13 & 4 \\
\hline \multirow{5}{*}{ Income } & $<$ IDR 2.5 million & 66 & 21 \\
\hline & IDR 2.6 million - IDR 5 million & 69 & 22 \\
\hline & IDR 5 million - IDR 7.5 million & 39 & 13 \\
\hline & $\begin{array}{c}\text { IDR } 7.6 \text { million - IDR } 10 \\
\text { million }\end{array}$ & 53 & 17 \\
\hline & $>$ IDR 10 million & 83 & 27 \\
\hline \multirow{4}{*}{ City of residence } & Greater Jakarta & 143 & 46 \\
\hline & Yogyakarta & 82 & 26 \\
\hline & Semarang & 48 & 16 \\
\hline & Bali & 36 & 12 \\
\hline
\end{tabular}

As many as $93 \%$ of respondents in this study stated that they buy red rice more often than black rice. They mostly or $43 \%$ received information from families regarding pigmented rice. Respondents in this study also bought more pigmented rice in packs. The reasons for the respondents consuming pigmented rice, among others, $46 \%$ stated that the nutritional content of pigmented rice was a source of fiber and vitamins, while $33 \%$ stated 
that pigmented rice provided health benefits. The frequency of consumption of pigmented rice by respondents still varies, this can actually be a business opportunity for pigmented rice to be better in the future and become the main choice for consumers.

Table 2. Respondent behavior

\begin{tabular}{|c|c|c|}
\hline Variable & Frequency & Percentage \\
\hline \multicolumn{3}{|l|}{ The type of rice that is purchased more frequently } \\
\hline Red rice & 290 & 94 \\
\hline Black rice & 19 & 6 \\
\hline \multicolumn{3}{|l|}{ Source of pigmented rice information } \\
\hline Friends & 53 & 17 \\
\hline Family & 130 & 42 \\
\hline Sales & 6 & 2 \\
\hline Social media, advertising & 62 & 20 \\
\hline Print media, articles, journals & 49 & 16 \\
\hline Others & 9 & 3 \\
\hline \multicolumn{3}{|l|}{ Purchase pigmented rice } \\
\hline Packaged pigmented rice & 226 & 73 \\
\hline Retail pigmented rice, without packaging & 83 & 27 \\
\hline \multicolumn{3}{|l|}{ The frequency of consumption of pigmented rice } \\
\hline Everyday & 46 & 15 \\
\hline Two times a week & 68 & 22 \\
\hline Three times a week & 40 & 13 \\
\hline Others & 155 & 50 \\
\hline \multicolumn{3}{|l|}{ Reasons for consuming pigmented rice } \\
\hline Nutritional content (source of fiber, vitamins, etc.) & 142 & 46 \\
\hline Provides health benefits & 102 & 33 \\
\hline On a diet & 59 & 19 \\
\hline Others & 6 & 2 \\
\hline
\end{tabular}

\subsection{Instrument Test}

\subsubsection{Validity Test}

Table 3. Validity Test

\begin{tabular}{|c|c|c|}
\hline Indicator & r-value & r-table \\
\hline \multicolumn{3}{|l|}{ Attitude towards green product } \\
\hline I believe that buying organic pigmented rice helps reduce water and soil pollution. & 0.825 & 0.264 \\
\hline I believe that buying organic pigmented rice helps save nature and its resources. & 0.854 & 0.264 \\
\hline I choose to buy pigmented rice if it has an organic or eco-friendly label. & 0.792 & 0.264 \\
\hline I choose to buy organic pigmented rice with recyclable packaging. & 0.862 & 0.264 \\
\hline I choose to eat organic pigmented rice because it is a healthy food. & 0.701 & 0.264 \\
\hline The trend to buy eco-friendly products is increasing in my neighborhood. & 0.693 & 0.264 \\
\hline When buying products, environmental protection is important to me. & 0.869 & 0.264 \\
\hline \multicolumn{3}{|l|}{ Green purchase intention } \\
\hline I intend to buy organic pigmented rice. & 0.897 & 0.264 \\
\hline I am interested in buying organic pigmented rice & 0.855 & 0.264 \\
\hline I intend to recommend to families to buy organic pigmented rice. & 0.586 & 0.264 \\
\hline I intend to recommend to my friends to buy organic pigmented rice. & 0.796 & 0.264 \\
\hline $\begin{array}{l}\text { For ecological reasons I will consider switching to environmentally } \\
\text { friendly products }\end{array}$ & 0.789 & 0.264 \\
\hline $\begin{array}{l}\text { In the future, I expect to buy environmentally friendly products because } \\
\text { they have a positive contribution }\end{array}$ & 0.658 & 0.264 \\
\hline I intend to buy eco-friendly products as gifts to the closest people & 0.859 & 0.264 \\
\hline
\end{tabular}


To measure indicators of attitudes towards green product and green product intention. In this study, the validity test was used. Based on Table (3), all indicators used in the study show that the $r$ value is higher than the $r$ table, this means that all indicators are valid and can be used in the research questionnaire.

\subsubsection{Reliability Test}

Based on the results of the reliability test in this study, it shows that all variables are reliable because they meet the requirements of Cronbach's alpha $>0.6$.

Table 4. Reliability Test.

\begin{tabular}{|c|c|}
\hline Variabel & Cronbach's Alpha \\
\hline Attitude towards green product & 0.858 \\
\hline Green purchase intention & 0.810 \\
\hline
\end{tabular}

\subsection{Regression}

\subsubsection{Normality Test}

Decision making for the normality test is normally distributed data if the significance value is greater than 0.05 . The normality test in this study used the Kolmogorov-Smirnov test. The results showed that the Kolmogorov Smirnov value was 0.085 with a significance value of 0.071 . Because the sig value $>0.05$, it can be concluded that the data residuals are normally distributed.

\subsubsection{Simple Linear Regression}

The results of the model summary analysis show that the $\mathrm{R}^{2}$ is 0.443 or $44.3 \%$. This means that the variable attitude towards green products is able to explain the variation of green purchase intentions by $44.3 \%$ and the remaining $55.7 \%$ is influenced by other variables not studied.

Table 5. Result of Model Summary.

\begin{tabular}{|c|c|c|}
\hline Model & $\mathbf{R}^{\mathbf{2}}$ & Std. Error of the Estimate \\
\hline 1 & 0.443 & 1.880 \\
\hline
\end{tabular}

Based on the data in Table 6 , the significant value is 0.000 . These results indicate that the significant value is smaller than 0.05 . So it can be concluded that the regression model of the attitude variable towards green products simultaneously or jointly affects the green purchase intention variable.

Table 6. Result of ANOVA.

\begin{tabular}{|c|c|c|c|c|c|}
\hline Model & Sum of Square & df & Mean Square & F & Sig. \\
\hline Regression & 862,272 & 1 & 862,272 & 243,989 & .000 \\
\hline Residual & 1084,957 & 307 & 3,534 & & \\
\hline Total & 1947,230 & 308 & & & \\
\hline
\end{tabular}


This analysis is used to determine the degree or strength of the relationship between the attitude variable towards green products $(\mathrm{X})$ and intention to buy green products variable (Y). Based on table 6 , the regression equation is obtained as follows:

$$
\begin{gathered}
Y=a+b X \\
Y=6.968+0.738 X
\end{gathered}
$$

From the simple linear regression equation, the results can be described:

a. A constant of 6.968 means that if the independent variable is considered constant, then the resulting purchase intention was 6,968 times.

b. The regression coefficient for attitude towards green products $(\mathrm{X})$ is 0.738 , meaning that if the attitude towards green products has increased by 1 time, it will increase the purchasing decision by 0.738 times and vice versa.

The positive correlation value indicates that the relationship is unidirectional, where the better the attitude towards green products, the higher the green purchase intention will be.

Based on the SPSS test, the $\mathrm{t}$ value was 15.620 , while the $\mathrm{t}$ table value with a confidence level of 0.05 was 1.962 . The results of the $t$ value $>t$ table, this means that attitudes towards green products have a positive and significant effect on purchase intentions of green products.

Table 7. Coefficients

\begin{tabular}{|c|c|c|c|c|c|c|}
\hline \multicolumn{2}{|c|}{ Model } & \multicolumn{2}{|c|}{ Unstandardized Coefficients } & Standardized Coefficients & \multirow{2}{*}{ Sig. } \\
\cline { 3 - 5 } & B & Std. Error & Beta & & \\
\hline \multirow{2}{*}{1} & (Constant) & 6,968 &, 683 & & 10,199 &, 000 \\
\cline { 2 - 7 } & Attitude &, 738 &, 047 &, 665 & 15,620 &, 000 \\
\hline
\end{tabular}

\subsection{Attitude Towards Green Product}

In this study, 7 indicators represent the attitude variable towards green products. Most of the respondents believe that buying organic pigmented rice helps reduce water, soil pollution, helps save nature and its resources. Based on research [6] states that consumer attitudes towards environmentally friendly products can influence buying intentions and directly influence the buying behavior of environmentally friendly products. Consumers want to participate in protecting the environment by purchasing products that do not harm the environment. The more someone has a positive attitude towards the environment, the more they will encourage the purchase intention of green products or environmentally friendly products.

As many as $63.9 \%$ of consumers agree to choose to buy pigmented rice if it has an organic or eco-friendly label. Recycled packaging is also a consumer concern in choosing green products, $69.78 \%$ of respondents choose to buy pigmented rice with environmentally friendly packaging. To convince green consumers, manufacturers must provide packaging that is equipped with the basic functions of conventional packaging and features of environmental protection functions [21]. 
Table 8. Analysis of attitudes towards green products.

\begin{tabular}{|l|c|c|c|c|}
\hline \multicolumn{1}{|c|}{ Indicator } & \multicolumn{3}{c|}{ Percentage result from Likert scale } \\
\cline { 2 - 5 } & $\begin{array}{l}\text { Strongly } \\
\text { disagree }\end{array}$ & Disagree & Agree & $\begin{array}{c}\text { Strongly } \\
\text { agree }\end{array}$ \\
\hline $\begin{array}{l}\text { I believe that buying organic pigmented rice } \\
\text { helps reduce water and soil pollution. }\end{array}$ & 0.65 & 36.25 & 55.02 & 8.09 \\
\hline $\begin{array}{l}\text { I believe that buying organic pigmented rice } \\
\text { helps save nature and its resources. }\end{array}$ & 0.65 & 10.36 & 74.76 & 13.59 \\
\hline $\begin{array}{l}\text { I choose to buy pigmented rice if it has an } \\
\text { organic or eco-friendly label. }\end{array}$ & 1.26 & 9.15 & 63.9 & 25.69 \\
\hline $\begin{array}{l}\text { I choose to buy organic pigmented rice with } \\
\text { recyclable packaging. }\end{array}$ & 3.38 & 8.65 & 69.78 & 18.19 \\
\hline $\begin{array}{l}\text { I choose to eat organic pigmented rice because it } \\
\text { is a healthy food. }\end{array}$ & 0.85 & 6.25 & 62.95 & 29.95 \\
\hline $\begin{array}{l}\text { The trend to buy eco-friendly products is } \\
\text { increasing in my neighborhood. }\end{array}$ & 5.78 & 11.45 & 58.26 & 24.51 \\
\hline $\begin{array}{l}\text { When buying products, environmental protection } \\
\text { is important to me. }\end{array}$ & 8.35 & 22.68 & 53.35 & 15.62 \\
\hline
\end{tabular}

\section{Conclusion}

From the research done, it can be concluded that the attitude variable towards green products has a positive and significant effect on consumer purchase intentions of organic pigmented rice. In the significance test, the $t$ value $>t$ table is obtained, namely $15.620>$ 1.962, which means that the attitude variable towards green products has a significant effect on the purchase intention of environmentally friendly products or green products. The attitude variable towards green products can explain the variance of intention to buy environmentally friendly products by $44.3 \%$ and the residue of $55.7 \%$, which is influenced by other variables not examined in this study.

Based on the theory of planned behavior, a more positive attitude towards certain behaviors is the individual's opportunity to perform that behavior [17]. Research that has been done further supports the theory that there is a positive relationship between attitudes and purchase intentions. The research conducted by [20] on consumers in Qingdao, China, stated that attitudes have a positive and significant effect on consumer purchase intentions of green products. This is also supported by research on India's consumers conducted by $[21,22]$; the study results state that attitudes towards green products have a significant effect and the strongest variable that can influence consumer purchase intentions of environmentally friendly products.

\section{Recommendation and Future Research}

In order to promote and increase sales of organic pigmented rice, farmers or producers must be able to convince consumers that organic pigmented rice has good benefits for health and consumer needs and brings improvements to the environment so that consumers feel confident in their decision to buy organic pigmented rice. This can be done by making environmentally friendly packaging, writing down the benefits and nutritional content of pigmented rice on the packaging, and adding an organic or eco label logo. To support this, the government must also encourage the implementation of policy rules that protect the environment. 
Limitations in the use of the variables studied, namely limited to attitudes towards green products and green purchase intentions. In the future, more in-depth research is needed related to other variables that affect the purchase intentions of organic pigmented rice.

\section{References}

1. J. Paul, J. Rana, J Int Consum Mark., 29 (2012)

2. H. Yeon Kim, J. Eun Chung, J Int Consum Mark., 28 (2011)

3. S. Sriyanto, Panen duit dari bisnis padi organik (Agromedia Pustaka, Jakarta, 2010)

4. L. G. Schiffman, L. L. Kanuk, Consumer Behaviour (Prentice Hall, New Jersey, 2010)

5. N. Michaelidou, L. M. Hassan, Food Policy, 35 (2010)

6. R. Yadav, G. S. Pathak, J. Clean. Prod, 135 (2016)

7. Kristamtini, Taryono, P. Basunanda, R. H. Murti, Indonesian Journal of Agricultural Sciences, 17 (2014).

8. V. C. ristina Ito, L. G. Lacerda, Food Chem., 301 (2019)

9. M.W. Zhang, R.F. Zhang, F.X. Zhang, R.H. Liu, J. Agric. Food Chem, 58, 7580 (2010)

10. C.A. Setyanti, http://www.cnnindonesia.com/gaya-hidup/20150324133555-26241425/beras merah-cokelat-dan-hitam-mana-paling-sehat/ (2015)

11. A. Hassana, M. Z. Ismail, Procedia Soc Behav Sci., 15 (2011)

12. K. Hung, A.H. Chen, J. Prod. Brand. Manag, 20 (2011)

13. S. Wei, T. Ang, V. E. Jancenelle, J. Retail. Consum. Serv., 45 (2018)

14. R.A. Kerin, Marketing (McGraw-Hill Education, New York, 2014)

15. M. Laroche, T. Lefa, H. Zhu, J Consum Mark, 24 (2017)

16. Y.R. Putri, Pengembangan strategi pemasaran beras hitam lokal Daerah Istimewa Yogyakarta sebagai pangan fungsional (2019)

17. I. Ajzen, Agric Econ, 70 (2015)

18. Y. Joshi, Z. Rahman, Manag. Environ. Qual, 27 (2016)

19. M.F. Chen, Br Food J, 3 (2016)

20. X. Qi, A. Ploeger, Appetite, 133 (2019)

21. J. Paul, A. Modi, J. Patel, Retail. Consum. Serv, 29 (2016)

22. Y. Hao, H. Liua, H. Chena, Y. Shaa, H. Jia , J. Fan, Resour. Conserv. Recycl, 141 (2019) 